\title{
Collective narcissism and weakening of American democracy
}

\section{Oliver Keenan $^{1} \quad$ Agnieszka Golec de Zavala ${ }^{1,2,3}$}

\author{
${ }^{1}$ Department of Psychology, Goldsmiths, \\ University of London, United Kingdom \\ 2 Department of Psychology, SWPS \\ University of Social Sciences and \\ Humanities, Poznan, Poland \\ ${ }^{3}$ ICSTE-IUL, Lisbon, Portugal

\section{Correspondence \\ Oliver Keenan, Department of Psychol- ogy, Goldsmiths, University of London, 8 Lewisham Way, New Cross, London SE14 6NW, UK. \\ Email: oliver.r.keenan@gmail.com}

\section{Funding information}

Data collection was supported by the National Science Centre (Grant 2017/26/A/HS6/00647) awarded to Agnieszka Golec de Zavala

\begin{abstract}
The storming of the US Capitol on January 6, 2021, and voter intimidation by Donald Trump's supporters have marked significant upheaval in American democracy. In two cross-sectional studies and one experiment, we tested the proposition that American collective narcissism is associated with support for populist leadership (particular, their message of renewed ingroup recognition) to the point of disregard for democratic procedures. In Study 1, conducted just before the 2020 presidential elections, we examined the association of American collective narcissism with support for Trump's re-election even if he was to violate the democratic procedures while securing it. In pre-registered Study 2, conducted just after the Capitol attack, we examined the association between American collective narcissism and support for the attacks. In Study 3, we experimentally examined a more general proposition that collective narcissism is associated with support for populist leaders and lack of support for democratic procedures, in a minimal group setting deprived of any associations with a particular political context. The results of the three studies converge to indicate that collective narcissism is most strongly (beyond variables commonly implicated in support for right-wing populism) associated with populist leadership to the extent of disregarding democratic norms.
\end{abstract}


[T] he explicit focus of "hate rhetoric" is frequently on who "we" are and this leaves implicit (but obvious) who is excluded. ... once it is evident who "they" are and that "they" endanger us, then a focus on ingroup vulnerability and ingroup virtue is sufficient to legitimate intergroup violence.

- (Reicher et al., 2005, p. 632)

... But those days are over. We will no longer tolerate such abuse. We will not allow our workers to be victimized, our companies to be cheated, and our wealth to be plundered and transferred. America will never apologize for protecting its citizens.

— (Donald Trump's Address to United Nations, 2018)

America is fulfilling our destiny as peacemaker, but it is peace through strength.

— (Donald Trump's Address to United Nations, 2020)

Since rioters stormed the Capitol on January 6, 2021, to challenge the certification of Electoral College votes, Donald Trump has come under increased criticism and faced an impeachment trial for his rhetoric inciting his followers toward violence (Connolly \& Riotta, 2021). In particular, Trump's message since the election-an allegation that the presidency was unjustly stolen from him in a fraudulent, irregular contest that should be reversed-has been identified as a major factor in leading supporters to endorse his rejection of democratic procedures and results (Woodward, 2021). Donald Trump is an accomplished populist leader (Reicher \& Haslam, 2016), who mobilizes his supporters by defining American national identity in terms of vulnerable greatness and threatened entitlement (Hogg \& Gøtzsche-Astrup, 2021; Kruglanski et al., 2021). He proposes himself as a warrant of national renewal to re-establish the national superiority that is supposedly threatened or lost (Federico \& Golec de Zavala, 2018; Golec de Zavala \& Federico, 2018).

Earlier work identified American collective narcissism-a belief that the national ingroup's exaggerated greatness is insufficiently recognized by others (Golec de Zavala et al., 2009, 2019; Golec de Zavala \& Lantos, 2020) — as a major predictor of support for Trump's presidential candidacy in the 2016 elections (Federico \& Golec de Zavala, 2018). Since then, national collective narcissism has been linked to support for illiberal right-wing populist leaders, parties, and policies worldwide (for reviews, see Golec de Zavala \& Keenan, 2021) and moral double standards in evaluating such leaders (Bocian et al., 2021). As collective narcissism is associated with an exclusive definition of the ingroup and readiness for intergroup hostility (for recent reviews see Golec de Zavala et al., 2019; Golec de Zavala \& Lantos, 2020), the previous studies predicted that Trump's presidency and an increased, mainstream presence of collective narcissism as a dominant narrative about national identity would mobilize its adherents around the promise of renewed ingroup recognition. The Capitol attack can be seen as an effect and illustration of such a construction of national identity, particularly when this identity was threatened by its representative's loss of power. We claim that it happened because collective narcissism is associated with support for pop- 
ulist leaders to the point of disregard for democratic procedures, seen as an obstacle to the shared national identity.

In line with this prediction, studies show that national collective narcissism is robustly associated with right-wing authoritarianism (i.e., obedience to convention and authority and the rejection of deviants; Altemeyer, 1988) and thus, it is likely to predict support for undemocratic leadership defined by strength and centralization of power (Golec de Zavala et al., 2009, 2019). Authors also agree that the belief that others constantly threaten the ingroup's exceptionality is used to justify group-centrism, that is, hierarchical organization of the group with tightly controlled norms and authoritarian leadership defined by strength (Hogg \& Gøtzsche-Astrup, 2021). In the present research, we examine collective narcissism's associations with support for Donald Trump using undemocratic methods to stay in power before the elections, support for Capitol attacks after the elections, and support for a generic political candidate advocating renewal of national greatness even by means that may undermine the rule of law.

\section{COLLECTIVE NARCISSISM AS BASIS OF POPULIST ATTITUDES}

Collective narcissism forms the basis of populist attitudes as it puts the perceived needs (i.e., concerning proper recognition) of a narrowly construed national ingroup, over that of the wider national membership or society (e.g., Brexit; Golec de Zavala et al., 2017). National collective narcissism expresses concerns over the national ingroup losing (or having lost) what it was entitled to have: the recognition of its supremacy and admiration of others (Golec de Zavala et al., 2009). Collective narcissism is associated with negative, highly sensitive emotionality a, hypervigilance to any threats to the group, and retaliatory aggression even to ambiguous or imagined (e.g., conspiratorial) threats (Golec de Zavala et al., 2016; Golec de Zavala \& Lantos, 2020). This suggests that the main concern associated with collective narcissism is the external perception of the national image rather than the legal organization of the state that serves the nation. Indeed, democratic organization may be seen as ineffective in preserving or renewing the allegedly undermined external recognition of national greatness.

Democratic systems, which involve incremental change through diverse group decisions, are likely to be seen as ineffective by those who perceive their ingroup's privilege under threat. Instead, a strong leader capable of doing what is needed to restore the nation's proper place and external recognition will be preferred (Sprong et al., 2019; Spruyt et al., 2016). Populist leaders act to represent this exclusive version of the group, coordinating and mobilizing its members around renewing ingroup recognition; the bond that results for its members driving aggression against those outside the "national community" (Kunst et al., 2019). Protecting the ingroup's desired external recognition can be used to harshly sanction excluded group members, for example, women who do not conform to traditional gender roles (Golec de Zavala \& Bierwiaczonek, 2021) and sexual minorities (Mole et al., 2022).

A narrow and exclusive ingroup construal drives anti-democratic collective action in order to protect and bolster traditional ingroup hierarchies (e.g., of race) through reactionary right-wing movements (Capelos \& Katsanidou, 2018; Selvanathan et al., 2021). Collective narcissism shares with authoritarianism this narrow normative view of the group and with social dominance orientation (a preference for maintaining group-based hierarchies; Pratto et al., 1994) its justification of group inequality (Golec de Zavala et al., 2019), which are both associated with anti-democratic attitudes. A group-centric definition of American identity predicts support for Donald Trump enacting antidemocratic policies, such as the registering of all Muslim Americans under the pretext of 
anti-terrorism (Dunwoody \& Plane, 2019), and autocratic attitudes (e.g., abolishing elections so the president can decide everything) allow for the subordinating of low-status groups so higher status groups can maintain and further their position (Bartusevičius et al., 2020). Therefore, collective narcissism should be associated with action, which violates democratic procedures. Though, when this action is seen to secure the ingroup's recognition, as promised by the populist message, we expect collective narcissism to be independently and more strongly associated with support for populist leadership (over and above, right-wing authoritarianism and social dominance orientation).

\section{The message of the populist leader}

The populist message should empower and mobilize those who hold the narcissistic belief about the national ingroup, where individual group members can rally behind an identity leader and forge a shared direction (Golec de Zavala \& Keenan, 2021; Mols \& Jetten, 2020), allowing for collective action such as the Capitol Hill raid. In its content, the populist message constructs politics as a conflict between the morally true "common people" and the morally corrupt politicians and "elites" who only represent their own interests (Mudde \& Kaltwasser, 2018). The inclusion of contesting groups' viewpoints and accountability of state power is an obstacle to populist leaders as the direct embodiment of the will of the "people" (Kaltwasser, 2012). Reicher and Haslam (2016) argue that Donald Trump uses the frame of the American Jeremiad to present his platform organized around "Make America Great Again."

Jeremiad identifies a point in history from which the nation started to decline. The message promises to remake the group's significance and to make us special-people are drawn to the cause of a renewed, exceptional group membership (see also Mols \& Jetten, 2014; Wohl \& Stefaniak, 2020). The message is based on a theme that others should be awed by the ingroup, but not only are they falling short of being awed but are in fact disrespectful and constantly wronging the group. This messaging both validates and promises to rectify the narcissistic belief about the group so that others will be made to recognize the group's significance. As such, this message may be convincing to people who endorse national collective narcissism. Indeed, studies show that national collective narcissism predicts support for populist politicians, parties, and politics worldwide (Golec de Zavala \& Keenan, 2021; Golec de Zavala et al., 2017; 2021; Marchlewska et al., 2018). As populist leaders legitimize collective narcissism as a form of shared national identity, hostile reactions (e.g., the Capitol Hill raid) to a perceived threat to this identity (e.g., through the election loss of its empowering representative) become a matter of time.

\section{Current research}

In three cross-sectional studies, we tested whether collective narcissism predicts acceptance for the violation of democratic procedures in support of populist leadership. With ecological validity in mind, we first tested this prediction using Donald Trump as an exemplar populist leader (Reicher \& Haslam, 2016). We collected data in two time points around the American presidential election: Study 1 just before in November 2020 and Study 2 several months after in March 2021. In Study 1, we tested whether American collective narcissism was positively associated with support for Trump using undemocratic means to extend his presidency (Hypothesis 1). Given that Trump is a prime representative of the populist message, this closely approximates how renewed 
ingroup recognition is given precedence to the detriment of democratic procedures. In Study 2, we tested whether American collective narcissism was positively associated with favorable attitudes toward the Capitol Hill, a direct challenge to the results of the democratic election (Hypothesis 2). Given the raid was to protest the results of a democratic election, this captures the extent to which violating democratic norms is justified if it is in the explicit interests of renewed ingroup recognition. This hypothesis was pre-registered (see https://aspredicted.org/42665.pdf). ${ }^{1}$

Next, in Study 3, with external validity in mind, we tested whether collective narcissism predicted support for a leader expressing an undemocratic populist message in a minimal group context (see e.g., Jetten et al., 2015) devoid of associations with any particular political context including American politics. This allowed us to assess the relationship without the influence of additional factors implicated in candidate support (i.e., politically motivated cognition; Leeper \& Slothuus, 2014), such as one's party membership. We tested whether people who endorse collective narcissism were attracted to the content of the populist leader's message (i.e., regaining collective significance is worth it by any means necessary) versus the messages of authoritarian (emphasizing national security and control over norms), nationalistic (emphasizing international supremacy), or democratic (emphasizing political inclusion and equality) leaders. We expected collective narcissism to be related to the endorsement of the populist message (especially in comparison to the democratic message) even in this scant context (Hypothesis 3).

Across the three studies, we aimed at establishing that the hypothesized association is specific to collective narcissism over and above relevant predictors of support for populist leaders identified by the literature. In Studies 1 and 2, we controlled for demographic variables, such as age, gender, income, and ethnicity, education, and national identification (viewing oneself as a prototypical of the national group), as these have been implicated in support for Trump's candidacy (Cook et al., 2017). We also controlled variables that are associated with a right-wing orientation and have predicted support for Trump: racial resentment (Abramowitz \& McCoy, 2019), political conservatism, and Republican party identification (Sides et al., 2018). In Studies, 2 and 3 we include measures of right-wing authoritarianism and social dominance orientation also associated with support for populism and Donald Trump in particular (e.g., Womick et al., 2019). In all studies, we also controlled for ingroup positivity, measured using the national ingroup satisfaction scale (positive feelings about one's group membership; Leach et al., 2008) as American identity is often defined by positive emotional attachment to the national group (Citrin et al., 2001), which has been associated with support for Trump (Hanson \& O’Dwyer, 2019).

The studies were reviewed and accepted by the Research Ethics Committee at Goldsmiths, University of London. All participants provided informed consent and were fully debriefed. A priori sample size estimation was carried out using $\mathrm{G}^{*}$ Power for multiple regression analysis with eleven predictors. We conservatively assumed a medium effect size of $f^{2}=.19$, based on the smallest effects size for the association between collective narcissism and populism found in the literature: $R^{2}$ contribution to support for Brexit vote (Marchlewska et al., 2018). The sample estimate (based $80 \%$ power at $\alpha=.05$ ) was $n=99$ for Study 1, $n=106$ for Study 2 (with the inclusion of two additional predictors). In Study 3 , we set the $\alpha=.01$ considering repeated comparisons across multiple outcome measures, the sample estimate was $n=105$, with five predictors. We oversampled in each study following the suggestion that correlation sizes stabilize at around $n=250$ (Schönbrodt \& Perugini, 2013).

\footnotetext{
${ }^{1}$ The preregistration specified an additional study design and hypotheses, which was made impossible because of participant attrition.
} 
TA B L E 1 Factor analysis for Trump election challenge measure

\section{Items}

Factor loadings

1. President Trump expressed the will to stay in the Oval Office beyond his .913 constitutionally allotted two terms. He should be able to if he wants to

2. If we have a good President, we should not hold presidential elections every 4 years

3. I would like President Trump to win the elections even if he had to compromise the rule of law

4. I would like my candidate to win the presidential election even if it meant he had to bend the rules of democracy

5. I would like President Trump to win the elections even if the Supreme Court had to go against the popular vote

\section{STUDY 1}

\section{Participants and design}

Participants $(n=308$; female $=136$, male $=172$; age: $\mathrm{M}=38.81, \mathrm{SD}=12.57$. range: $21-81)$ were Amazon MTurk workers who were adult citizens of the United States who took part in a cross-sectional survey programmed on Qualtrics. Participants who failed attention checks during participation were redirected away from the survey to ensure only high-quality data was collected.

\section{Measures}

Unless otherwise indicated, the continuous variables were measured using a 7-point scale for each item ranging from 1 (strongly disagree) to 7 (strongly agree).

Collective narcissism ( $\alpha=.90, \mathrm{M}=4.72, \mathrm{SD}=1.45$ ) was measured using a 5 -item version of the Collective Narcissism Scale (Golec de Zavala et al., 2009, used in previous studies, e.g., Golec de Zavala et al., 2013), for example, "The United States deserves special treatment."

A measure of support for Trump's candidacy regardless of democratic procedures was constructed for the purpose of this study. A confirmatory factor analysis with robust maximum likelihood estimation validated a one-factor scale with good fit, Comparative Fit Index (CFI) = .996; Root Mean Square Error of Approximation (RMSEA) = .05, 90\% Confidence Intervals (CI) [0.00, 0.10], $p_{\text {close }}=.447$ (Table 1 ). The 5-item measure tapped support for Trump's autocratic challenge to 2020 US election scale $(\alpha=.94, \mathrm{M}=4.35, \mathrm{SD}=1.73$ ). The full list of items can be found in the Supplemental Materials, the items presented are those selected on face validity as most consistent with the concept of interest.

\section{Control variables}

Following previous research (Federico \& Golec de Zavala, 2018), we included as control variables: age (rescaled to five ordered categories: (1) $18-24, n=5$; (2) 25-35, $n=153$; 36-45, $n=62$; 46-55, $n=42 ; 56+, n=46$ ), income (nine ordered categories: (1) less than $\$ 10,000, n=16$; (2) $\$ 10,000-$ $\$ 14,999, n=15$; (3) \$15,000-\$24,999, $n=28$; (4) $\$ 25,000-\$ 34,999, n=38$; (5) $\$ 35,000-\$ 49,999, n$ $=54$; (6) $\$ 50,000-\$ 74,999, n=92$; (7) $\$ 75,000-\$ 99,999, n=37$; (8) $\$ 100,000-\$ 149,999, n=18$; (9) 
TA B LE 2 Multiple regression analysis of predictors on support for Trump election challenge

\begin{tabular}{lccc}
\hline Predictors & $\mathbf{b}$ & $\mathbf{9 5 \%} \mathbf{C I} \mathbf{L L}, \mathbf{U L}$ & $\mathbf{p}$ \\
\hline (Intercept) & -0.37 & $-0.66,-0.08$ & .460 \\
Age & -0.01 & $-0.08,0.06$ & .798 \\
Male & -0.00 & $-0.15,0.14$ & .975 \\
Income & -0.10 & $-0.17,-0.03$ & $\mathbf{. 0 0 5}$ \\
College educated & 0.32 & $0.09,0.55$ & $\mathbf{. 0 0 6}$ \\
White ethnicity & -0.04 & $-0.21,0.12$ & .618 \\
National membership & 0.23 & $0.00,0.45$ & $\mathbf{. 0 5 0}$ \\
Racial resentment & 0.04 & $-0.07,0.14$ & .507 \\
Ingroup satisfaction & -0.14 & $-0.22,-0.05$ & $\mathbf{. 0 0 1}$ \\
National collective narcissism & 0.73 & $0.62,0.84$ & $<.001$ \\
Conservatism & 0.14 & $0.06,0.22$ & .001 \\
Republican & -0.09 & $-0.23,0.05$ & .202 \\
Observations & 308 & & \\
$R^{2} / R^{2}$ adjusted & $0.668 / 0.655$ & & \\
\hline
\end{tabular}

Note. The standardized regression coefficients presented are from robust estimation using heteroscedasticity-consistent standard errors.

$\$ 150,000-\$ 199,999, n=10)$, gender ( $0=$ female, $1=$ male), education (seven ordered categories: (1) Less than high school, $n=1$; (2) High school diploma or equivalent, $n=14$; (3) Some college, $n$ = 36; (4) Associate's degree, $n=24$; (5) Bachelor's degree, $n=182$; (6) Master's degree, $n=48$; (7) Advanced degree, $n=3$; recoded 1 for a bachelor's degree and above, 0 for below), self-identified race (Black, $n=19 ;$ Asian, $n=11$; Native American, $n=24$; White, $n=251$; Other, $n=3$; $\operatorname{coded}$ as $1=$ White ethnicity, $0=$ non-white), a binary measure of national identification $(1=$ viewing oneself as a prototypical American), as well as a measure of national ingroup satisfaction measured by a 4-item scale (Leach et al., 2008; $\alpha=.89, \mathrm{M}=5.62$, $\mathrm{SD}=1.07$ ) for example, "I am glad to be American" and "It is pleasant to be American." We also controlled for two political predispositions: 7-point measure of conservative (vs. liberal) self-placement ( $\mathrm{M}=4.36, \mathrm{SD}=1.79$ ) and partisanship, which was binary coded (1) for Republican (including 11 republican leaners; $n=146$ ) and (0) for Democrats (including 16 leaners and 11 who supported neither; $n=161$ ).

\section{Results and discussion}

Analyses were conducted in R v4.0.2 (R Core Team, 2013) with the use of the tidyverse (Wickham et al., 2019) for data preparation and the sjPlot package (Lüdecke, 2021) for tables and figures. In order to test Hypothesis 1, that collective narcissism would be associated with support for Donald Trump staying in power even while illegally challenging the democratic election, over and above related predictors, a multiple regression analysis was conducted including American collective narcissism as a predictor, support for Trump as the outcome variable, and all other variables as controls (Table 2). To account for heteroscedasticity and non-normality in the residuals, the multiple regression was adjusted to have robust standard errors through heteroscedasticity-consistent covariance matrix estimation (MacKinnon \& Whitehead, 1985), which produces reliable interval estimates under non-normality (Pek et al., 2018). Partial correlation coefficients were also calcu- 
Partial correlation coefficients for each variable with support for Trump election challenge

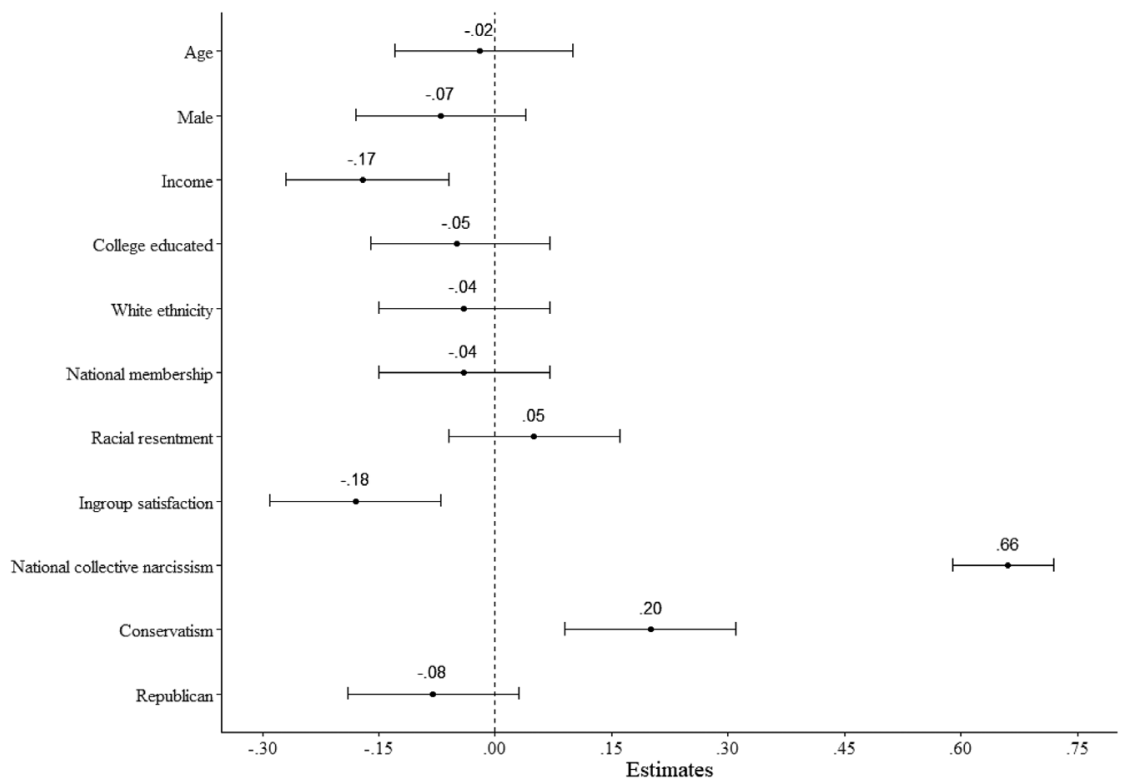

F I G U R E 1 Partial correlation coefficients for each variable with support for Trump election challenge

lated (Figure 1), providing a comparable effect size for the bivariate relationships of each variable with the outcome measure, while accounting for the overlap between all other variables. Consistent with Hypothesis 1, the results show that American collective narcissism is associated with endorsing Trump extending his presidency using undemocratic means. Moreover, standardized coefficients show that collective narcissism is by far the strongest predictor.

\section{STUDY 2}

\section{Participants and design}

Participants $(N=302$; male $=182$, female $=119$, other $=1$, age: $\mathrm{M}=38.53, \mathrm{SD}=11.29$, range $=$ 19.00-73.00) were Amazon MTurk workers who were adult citizens of the United States, who took part in a cross-sectional survey programmed on Qualtrics. As in Study 1, participants who failed attention checks during participation were redirected away from the survey.

\section{Measurements}

Participants responded using a 7-point scale for each item ranging from strongly disagree (1) to strongly agree (7).

Collective narcissism scale $(\alpha=.92, \mathrm{M}=3.98, \mathrm{SD}=1.62)$ was measured as in Study 1.

A scale $(\alpha=.91, \mathrm{M}=3.38$, SD 1.90) measuring attitudes endorsing the US Capitol raid was constructed for the purposes of this study. It was based on the populist rhetoric surrounding the attack, regarding Trump's claim that the election was stolen from him and that his presidency is 
TA B LE 3 Factor analysis for attitudes toward US Capitol raid

\section{Items}

1. Those who stormed the Capitol on January 6, 2021, were true Americans

2. The breaking into the Capitol was motivated by the love of freedom

necessary for national renewal (Aggarwal, 2021). A confirmatory factor analysis with robust maximum likelihood estimation validated a one factor with good fit, CFI $=.993$, RMSEA $=.09,90 \%$ CI $[0.03,0.15], p_{\text {close }}=.135$ (Table 3). The full list of items can be found in the Supplemental Materials; the items presented are those selected on face validity as most consistent with the concept of interest.

We included the following controls: age (rescaled to five ordered categories: (1) $18-24, n=11$; (2) $25-35, n=145$; (3) $36-45, n=76$; (4) 46-55, $n=41$; (5) $56+, n=29$ ), income (nine ordered categories: (1) less than $\$ 10,000, n=5$; (2) $\$ 10,000-\$ 14,999, n=12$; (3) $\$ 15,000-\$ 24,999, n=21$; (4) $\$ 25,000-\$ 34,999, n=35$; (5) $\$ 35,000-\$ 49,999, n=43$; (6) $\$ 50,000-\$ 74,999, n=91$; (7) $\$ 75,000-$ $\$ 99,999, n=44$; (8) $\$ 100,000-\$ 149,999, n=33$; (9) $\$ 150,000-\$ 199,999, n=18)$, gender ( $0=$ female, $1=$ male), education (seven ordered categories: (1) Less than high school, $n=0$; (2) High school diploma or equivalent, $n=22$; (3) Some college, $n=37$; (4) Associate's degree, $n=20$; (5) Bachelor's degree, $n=159$; (6) Master's degree, $n=57$; (7) Advanced degree, $n=7$; recoded 1 for a bachelor's degree and above, 0 for below), self-identified race (Black, $n=32$; Asian, $n=11$; Native American, $n=9$; White, $n=247$; Other, $n=3$; recoded as $1=$ White ethnicity, $0=$ non-White), a binary measure of national identification ( $1=$ viewing oneself as a prototypical American), and ingroup satisfaction ( $\alpha=.94 \mathrm{M}=5.34 \mathrm{SD}=1.33)$ measured as in Study 1 .

We controlled for two political predispositions: 7-point measure of conservative (vs. liberal) self-placement $(\mathrm{M}=3.94, \mathrm{SD}=1.91)$ and partisanship, which was binary coded (1) for Republican (including 11 republican leaners; $n=104$ ) and (0) for Democrats (including 23 leaners, and 22 who supported neither; $n=198)$. Furthermore, we controlled for authoritarianism ( $\alpha=.86, \mathrm{M}=5.59$, $\mathrm{SD}=1.05)$ measured with childrearing scale (Feldman \& Stenner, 1997) where participants rated their agreement for desirable qualities in children (e.g., respect for elders, obedience). We also controlled for social dominance orientation ( $\alpha=.80, \mathrm{M}=2.82, \mathrm{SD}=1.46)$ measured with the short 4item measure (Pratto et al., 2013), for example, "Superior groups should dominate inferior groups."

\section{Results and discussion}

In order to test Hypothesis 2 that collective narcissism is associated with support for the Capitol Hill raid, over and above control variables, we conducted a multiple regression analysis entering American collective narcissism as a predictor, support for Capitol Hill raid as the outcome variable, and all other variables as controls. Given heteroscedasticity and non-normality in the residuals, adjustment for robust standard errors was made as in Study 1. Consistent with our prediction, the analysis revealed a significant association between collective narcissism and support for the Capitol Hill raid. Standardized regression coefficients and partial correlations again showed collective narcissism to be the strongest predictor, ahead of the other two significant conceptual predictors: social dominance orientation and conservatism (Table 4, Figure 2) 
TA B L E 4 Multiple regression analysis of predictors on support for Capitol Hill raid

\begin{tabular}{lccc}
\hline Predictors & $\boldsymbol{b}$ & $\mathbf{9 5 \%} \boldsymbol{C I} \boldsymbol{L} \boldsymbol{L}, \boldsymbol{U L}$ & $\boldsymbol{p}$ \\
\hline (Intercept) & -0.23 & $-0.58,0.12$ & 0.311 \\
Age & -0.08 & $-0.15,-0.01$ & $\mathbf{0 . 0 3 1}$ \\
Male & 0.03 & $-0.10,0.16$ & 0.698 \\
Income & -0.08 & $-0.15,-0.01$ & $\mathbf{0 . 0 2 6}$ \\
College educated & 0.15 & $-0.03,0.33$ & 0.104 \\
White ethnicity & -0.10 & $-0.27,0.08$ & 0.289 \\
National membership & 0.20 & $-0.05,0.45$ & 0.121 \\
Racial resentment & -0.02 & $-0.11,0.07$ & 0.710 \\
Ingroup satisfaction & -0.01 & $-0.13,0.11$ & 0.855 \\
Collective narcissism & 0.47 & $0.34,0.60$ & $<\mathbf{0 . 0 0 1}$ \\
Conservatism & 0.15 & $0.05,0.24$ & $\mathbf{0 . 0 0 2}$ \\
Republican & 0.07 & $-0.11,0.25$ & 0.456 \\
Right-wing authoritarianism & -0.06 & $-0.18,0.06$ & 0.308 \\
Social dominance orientation & 0.34 & $0.22,0.45$ & $<\mathbf{0 . 0 0 1}$ \\
Observations & 302 & & \\
$R^{2} / R^{2}$ adjusted & $0.701 / 0.688$ & &
\end{tabular}

Note. The standardized regression coefficients presented are from robust estimation using heteroscedasticity-consistent standard errors.

Partial correlation coefficients for each variable with support for Capitol breach

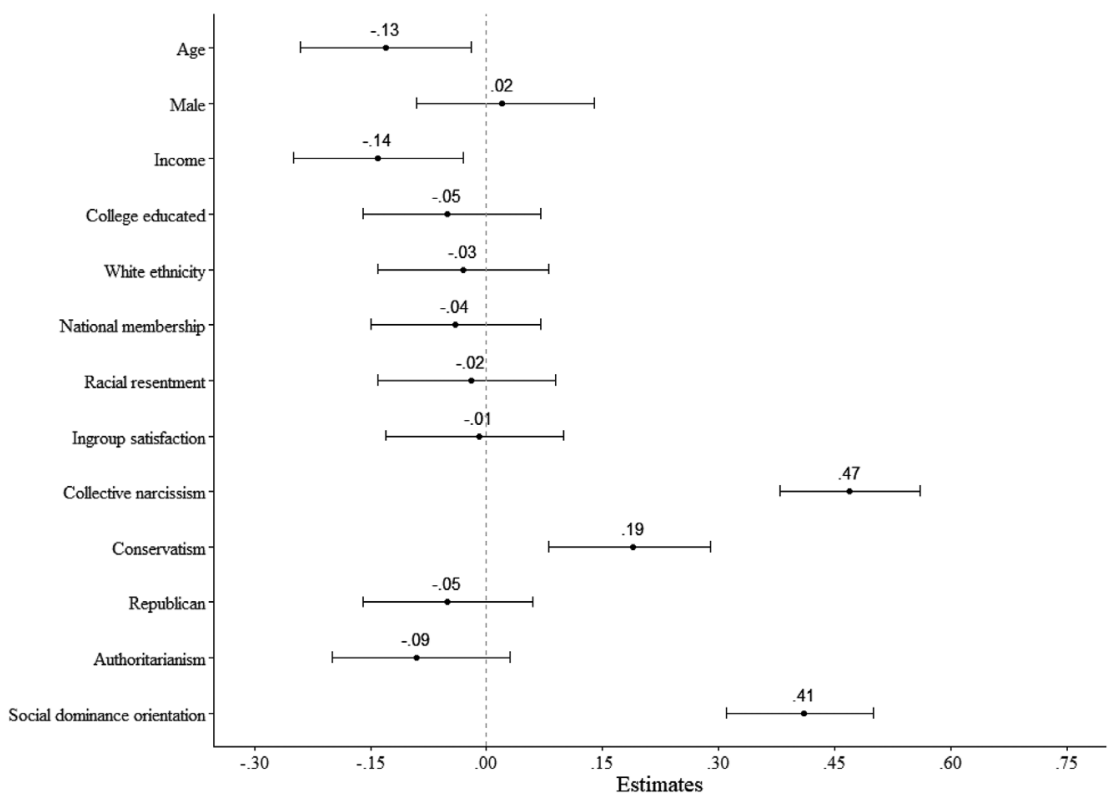

F I G U RE 2 Partial correlation coefficients for each variable with support for Capitol breach 
Results of Studies 1 and 2 are consistent with the expectations that people who endorse a narcissistic belief about America support Donald Trump's antidemocratic incitements and his staying in power while violating democratic procedures. In Study 3, we test whether the link between collective narcissism and support for populist leaders and their undemocratic message generalizes beyond the particular political context.

\section{STUDY 3}

\section{Method}

\section{Participants}

Participants were Amazon MTurk workers with an additional convenience sample of 48 participants $(N=217$; female $=93$, male $=121$, other $=3$; age: $\mathrm{M}=31.49, \mathrm{SD}=11$, range: $18-86)$; the survey was programmed using Qualtrics. The survey did not ask for details of participants' nationality, as it was focused on their fictional group membership. One hundred participants were excluded on the basis of incomplete responses.

\section{Design}

A within-participants experimental design was used, with the leadership vignettes taken as the experimental factor with four levels (populist, authoritarian, nationalist, democrat) across five conceptually related covariates: ingroup satisfaction, conservatism, collective narcissism, social dominance orientation, and right-wing authoritarianism. Age and gender were also included as control variables. Leadership endorsement was taken as the dependent variable.

\section{Procedure}

Participants expressed informed consent to participate in the study that allegedly tested how emotions influenced participation in a text-based role-playing game. As part of an alleged mental visualization task, participants were introduced to a fantasy land that had two neighboring countries-Bray and Minay. Participants then gave their preference for one of two abstract paintings and responded to a bogus personality test, which allegedly helped to assign them as members of Minay. Participants were then asked to give their opinion on being new members of Minay and completed the collective narcissism and ingroup satisfaction measures with reference to the nation of Minay. Next, participants took part in a naming ceremony, giving themselves a name that they would use as a group member and "met" other members of Minay in narrative format. This was followed by the completion of the right-wing authoritarianism and social dominance orientation measures, having been told the "other members" were interested in their political views. They were then told they would take part in the elections that were taking place. They viewed the leadership profiles on a single page and provided the endorsement scores for all competing leaders. Finally, they were probed for guessing (nobody guessed the hypothesis), thanked, and debriefed. 


\section{Measures}

\section{Covariates}

We controlled for demographic variables: age and gender.

Conservatism $(M=4.96, S D=2.95)$ measured on a 1-10 scale from very liberal to very conservative.

Responses on all covariates below were coded on a scale from 1 (strongly disagree) to 7 (strongly agree).

Ingroup satisfaction measured using the ingroup satisfaction scale $(\alpha=.84, \mathrm{M}=5.69, \mathrm{SD}=$ 0.99), e.g., "I think that the Minayzirith have a lot to be proud of," "I am glad to be Minayzirith).

Right-wing authoritarianism ( $\alpha=0.89, \mathrm{M}=3.53, \mathrm{SD}=1.08$ ) was measured using an 18-item scale (Duckitt et al., 2010), for example, “The 'old-fashioned ways' and 'old-fashioned values' still show the best way to live."

Social dominance orientation ( $\alpha=0.83, \mathrm{M}=3.11, \mathrm{SD}=1.27$ ) was measured using the 8-item scale (Ho et al., 2015), for example, "An ideal society requires some groups to be on top and others to be on the bottom."

Collective narcissism ( $\alpha=.92, \mathrm{M}=4.30, \mathrm{SD}=1.68$ ) was measured on the 5-item collective narcissism scale (Golec de Zavala et al., 2009) with reference to the make-believe ingroup, for example, "The Minayzirith deserve special treatment," "I will not be satisfied until Minay gets all that it deserves.” Responses were coded on a scale from 1 (strongly disagree) to 7 (strongly agree).

\section{Dependent variable}

Leadership endorsement was measured on two separate ratings indexing "feelings of warmth" and "likelihood to vote for" the respective leadership profiles. Participants responded on 0-100 visual analogue scales for both ratings. These two scores were averaged to give a composite measure of leader endorsement: populist $(r=.83, p<.001 ; \mathrm{M}=44.46, \mathrm{SD}=28.57)$, authoritarian $(r=.89, p<$ $.001 ; \mathrm{M}=46.10, \mathrm{SD}=28.73)$, nationalist $(r=.88, p<.001 ; \mathrm{M}=40.48, \mathrm{SD}=30.64)$, and democratic $(r=.77, p<.001 ; \mathrm{M}=70.10, \mathrm{SD}=20.16)$. These measures was transformed into long format in the dataset to create the four level within-factor and the single leadership endorsement outcome measure.

\section{Stimuli}

Participants read profiles (for verbatim see Supplemental Material) for the different candidates. The candidates emphasized political directions for the group of Minay, providing the gist of its intended national and foreign policy. These different messages about the group follow from research that shows that framing issues congruent with the worldviews of the audience lead to a greater endorsement (Crawford et al., 2013). The profiles were provided on a single page, which had the warmth and likelihood to vote measures under each vignette. This followed on from being told that they had gained "full membership" as a "Minayzirith" (national citizen), and it was now important to give their opinion on political candidates for an upcoming election.

The populist candidate vignette emphasized the paramount importance of ingroup renewal so that the ingroup would finally be seen as exceptional, and that this might require taking action "by any means," against those who do not recognize the ingroup's uniqueness. The authoritarian 
candidate vignette followed from the model of authoritarian governance emphasizing collective security and tightly controlled group norms, suggesting the reasonableness of using force against those who threaten the group's safety and values (Harms et al., 2018). The nationalist candidate vignette followed nationalist attitudes, which emphasize the importance of power and status and suggests that military assertiveness over other nations was reasonable (Kosterman \& Feshbach, 1989; Osborne et al., 2017). The democratic message followed a theoretical model of democratic governance, focusing on political equality and national inclusion of diverse groups, where cooperation is an important value (Dahl, 2008).

\section{RESULTS}

Assumption checks indicated non-normality in the residuals ${ }^{2}$; standard errors were adjusted through cluster-robust variance estimation with the clubSandwich R package (Pustejovsky \& Tipton, 2018). To test Hypothesis 3 that collective narcissism would be associated with support for the populist message (vs. the other leader messages, especially the democratic message) about the group, we ran a linear mixed model using the nlme R package (Pinheiro et al., 2017), which included random intercepts across participants to account for the leadership vignette withinfactor. We dummy coded the factor variable so the populist leader was treated as the base level across three pairwise comparisons with the other levels (i.e., vs. authoritarian, nationalist, and democratic). We Bonferroni adjusted the alpha level to .01 to conservatively account for inflated Type 1 errors from the repeated analyses. We included age and gender variables as controls, along with the predictor variables and their interaction terms across the levels of the factor variable, with leadership endorsement ratings taken as the dependent variable. The results for the interactions are shown in Table 5, where negative coefficients indicate a positive rating of the populist leader relative to the other leaders. Consistent with Hypothesis 3, collective narcissism significantly favored the populist leader over the democratic leader, independently of the other covariates. Right-wing authoritarianism and social dominance orientation also significantly favored the populist leader over the democratic leader, consistent with previous research. Ingroup satisfaction was non-significantly associated with the democratic leader (vs. populist), though the confidence intervals indicate a leaning toward the democratic leader. This is consistent with our expectation that it is narcissistic group identification (vs. non-contingent forms of positive identification) that predicts endorsement of populist leadership. Collective narcissism was nonsignificantly associated with the populist leader, compared to either the authoritarian or the nationalist leader; however, the confidence intervals indicate a strong leaning toward the populist leader.

Conservatism and social dominance orientation significantly favored the nationalist leader over the populist. This indicates that realistic group superiority is more important to self-rated conservatives and social dominators than symbolic recognition of the group's superiority. Right-wing authoritarianism significantly favored the populist over the nationalist. It was positively, but nonsignificantly, associated with the authoritarian leader. This suggests that both authoritarian leaders and populist leaders are highly relatable for right-wing authoritarians and collective narcissists.

\footnotetext{
${ }^{2}$ The same analysis was also ran excluding the single identified outlier, with no meaningful changes to the estimates. The results of this analysis can be found in the Supplemental Materials.
} 
TA B LE 5 Linear mixed model for within-participant interactions across the covariates on leadership

\begin{tabular}{|c|c|c|c|c|}
\hline \multicolumn{2}{|l|}{ Interactions } & \multicolumn{3}{|c|}{ Leadership endorsement } \\
\hline Covariates & Populist (-) vs.: & $\bar{b}$ & 95\%CI LL,UL & $p$ \\
\hline \multirow[t]{3}{*}{ Ingroup satisfaction } & Authoritarian & 0.05 & $-0.02,0.12$ & .141 \\
\hline & Nationalist & -0.03 & $-0.12,0.05$ & .473 \\
\hline & Democrat & 0.08 & $-0.02,0.17$ & .102 \\
\hline \multirow[t]{3}{*}{ Conservatism } & Authoritarian & 0.02 & $-0.06,0.11$ & .625 \\
\hline & Nationalist & 0.21 & $0.10,0.32$ & $<.001$ \\
\hline & Democrat & -0.14 & $-0.26,-0.02$ & .019 \\
\hline \multirow[t]{3}{*}{ Authoritarianism } & Authoritarian & 0.03 & $-0.12,0.17$ & .711 \\
\hline & Nationalist & -0.23 & $-0.35,-0.11$ & $<.001$ \\
\hline & Democrat & -0.54 & $-0.72,-0.37$ & $<.001$ \\
\hline \multirow[t]{3}{*}{ Social dominance orientation } & Authoritarian & 0.05 & $-0.07,0.16$ & .411 \\
\hline & Nationalist & 0.21 & $0.08,0.34$ & .002 \\
\hline & Democrat & -0.34 & $-0.52,-0.15$ & $<.001$ \\
\hline \multirow[t]{3}{*}{ Collective narcissism } & Authoritarian & -0.10 & $-0.21,0.01$ & .062 \\
\hline & Nationalist & -0.09 & $-0.20,0.01$ & .085 \\
\hline & Democrat & -0.25 & $-0.38,-0.11$ & $<.001$ \\
\hline
\end{tabular}

Note. Estimates are standardized regression coefficients with associated confidence intervals and $p$-values, from robust standard errors.

\section{General discussion}

The raid of the US Capitol Hill building on January 6, 2021, was an act of political violence that sought to overturn the result of the democratic election. We suggested that this attack was justified by the endorsement of national narcissism, which had been mobilized by Donald Trump during his presidency. The theme of the constant wrong done to the national ingroup (narrowed down to Trump's supporters) and the need to regain external recognition of national significance continued with Trump's incitement that his electoral loss to Joe Biden "the destroyer of American greatness" was fraudulent (Riley-Smith, 2020).

Anti-democratic and illiberal right-wing populism has established its presence around the globe. Some mainstream parties (e.g., the US Republican party and UK Conservatives; Bale, 2018; Sides et al., 2018) have adopted populism, and countries in Eastern Europe have rejected liberal democracy in favor of populist governments (e.g., Hungary or Poland; Forgas \& Lantos, 2020; Golec de Zavala et al., 2021). There is resurgent support for France's populist party National Front (Tidman, 2021), and Trump himself is running for re-election (Aggarwal, 2021). Central to populists' influence is their ability to successfully communicate to the collective narcissist belief about the national group. This coordinates the group with a collective goal of regaining its public significance (Golec de Zavala \& Keenan, 2021). Furthermore, this goal allows for preestablished democratic norms to be broken if perceived as an obstacle.

The results of the present studies converge to indicate that collective narcissism is associated with support for populist leaders to the point of accepting violations to democracy to keep them in power. In Study 1, conducted before the 2020 presidential elections, American collective narcissism predicted support for Trump illegally challenging the election if the results were not in his favor (e.g., did not win the popular vote) and extending his presidency even if it meant "bending 
the rule of law." Results of Study 2 affirmed this finding. They indicated that American collective narcissism was most strongly associated with support for the Capitol Hill raid, viewing it as in America's interest, namely, in "making America great again" and not as an insurrection against the result of a democratic election. In Study 3, this was further supported by the relationship between collective narcissism and favoring populist leader over democratic leader. This relationship was significantly different from another form of ingroup positivity (i.e., ingroup satisfaction), which showed a leaning toward the democratic leader. This relationship was also independent of the related predictors of conservatism, social dominance orientation, and right-wing authoritarianism.

This suggests that collective narcissism is a conception of the group that does not hold democratic norms as valuable. A key finding of this research is that collective narcissism is associated with support for a populist leader who rejects (or holds as unimportant) established democratic norms and enables polarization and political violence in the name of renewing the external recognition of the national ingroup's greatness. This shows that the potential for autocracy is not only driven by the internal status pursuit of group members (i.e., as is associated with social dominance orientation; Bartusevičius et al., 2020) but can be mobilized through the pursuit of the external recognition of a shared vision of collective significance.

Furthermore, collective narcissism was the strongest predictor of support for populist leadership across Studies 1 and 2, over and above all control variables: demographics, conservative political orientation, and other forms of national identification, such as prototypical membership and ingroup satisfaction. This attests to right-wing populism as predominantly a social identity-based process revolving around a particular framing of the group as deprived and wronged by others (Bos et al., 2020), which is clarified when collective narcissism is included as a predictor (e.g., in its association over national identification). Collective narcissism may be a key "thickener" (e.g., over-conservatism) to populism as a "thin-centred ideology" (i.e., lacking ideological breadth or development; Hawkins \& Kaltwasser, 2017). When populism draws on a narcissistic story about the national ingroup, it becomes configured (or thickened) to form a right-wing movement involving preference for inequality, tradition, and national superiority (Golec de Zavala et al., 2021). We would therefore expect collective narcissism to be closely associated with other normative views of the ingroup, which predict right-wing populism, such as collective psychological ownership (i.e., the national ingroup as "belonging" to a certain set of group members; Selvanathan et al., 2021), and antagonistic forms of collective nostalgia (e.g., a past time when the ingroup allowed the verbal hurting of others; Lammers \& Baldwin, 2020).

The findings from Studies 2 and (partially from) 3 corroborate the view that collective narcissism underpins a unique feature of right-wing populism as it predicts support for the populist message over and above (or more consistently than) right-wing authoritarianism and social dominance orientation. In the dual-process account of ideology (Duckitt, 2001), right-wing authoritarianism and social dominance orientation distinguish different motivational underpinnings of right-wing political orientation, respectively, ingroup security (from viewing the world as a dangerous place) and realistic competition (from viewing the world as competitive jungle). Importantly, this model shows how distinct sets of motivational goals can are associated with different (though related, e.g., as prejudicial attitudes) political outcomes (Duckitt \& Sibley, 2010). Accordingly, national collective narcissism expresses a motivation to regain national ingroup significance (from the worldview of the group as constantly disrespected by others) with implications for rightwing populist ideology, namely, that collective narcissism is most strongly responsive to a populist framing of the group. The findings extend research where authoritarians and social dominators more strongly endorse candidates that frame issues (e.g., abortion) in ways consistent with their 
beliefs (for instance, as a threat to religious values or to men's group status, Crawford et al., 2013). This taps the notion of "elective affinities" or relative strength of association between particular motivations and political ideas (and their representatives; Jost et al., 2009). Specifically, results from Study 3 that self-rated conservatism and social dominance orientation favor the nationalist leader while right-wing authoritarianism and collective narcissism favor the populist, suggest that populism is more ingroup-oriented (e.g., tight, conservative group boundaries), compared to nationalism's intergroup-orientation (e.g., competitive, expansionary; see Osborne et al., 2017). Furthermore, collective narcissism, though ingroup-oriented, may explain why right-wing populists become mobilized ostensibly as "anti-establishment" and against the mainstream of the group (Mondon \& Winter, 2020). This form of collective action is stimulated by reactionism or "resentful affectivity with the forceful desire to return to the past" (Capelos \& Katsanidou, 2018, p. 1272). Indeed, collective narcissists are constantly resentful over their negative belief about how others view the group and show negative emotional profiles (Golec de Zavala, 2019). This is unlike authoritarianism, which can promote or buffer wellbeing through just-world beliefs (Napier et al., 2020). We would expect collective narcissism to be associated with negative group-based emotions, which predict right-wing populism (see e.g., Marchlewska et al., 2018), such as group relative deprivation (Sengupta et al., 2019) and "anomie" (i.e., pessimism about society; Sprong et al., 2019).

Another approach involves a shift in perspective of collective narcissism as specific to individual differences in motivation, to being more broadly situated in social processes (Reynolds et al., 2010). Collective narcissism indicates a certain subjectively held social identity (i.e., concerning its unrecognized greatness), which can be shared across the societal context (Elcheroth et al., 2011). Social identities vary in content, for instance, in the interpretation of the group's history and defining qualities (Ashmore et al., 2004; Pehrson et al., 2009), emotions (Smith \& Mackie, 2015), values, and traits (Pagliaro et al., 2011; Turner-Zwinkels et al., 2015). It is expected that collective narcissism would be associated with social identity content that serves to legitimize group inequality, for example, a religious content, which motivates sexism against women perceived to destabilize the group (Golec de Zavala \& Bierwiaczonek, 2021).

Particularly, collective narcissism's emphasis on the ingroup's lack of recognition might serve as a common rubric for experiences of loss of entitlement (e.g., from the expansion of rights for minority groups; Golec de Zavala \& Keenan, 2021) and facilitate the alignment of subgroup identities (i.e., social sorting; Mason \& Wronski, 2018) within a simplified, highly exclusive national identity. Identity alignment is used by identity entrepreneurs who broaden their appeal by increasing perceptions of group coherence and hierarchical stability (Hogg \& Gøtzsche-Astrup, 2021), where populist leaders coordinate and represent particular subgroup norms as part of the national identity (McCoy et al., 2018). For example, Republican identity alignment with the religious rightwing by negotiation of "pro-life" as a value and policy (Williams, 2011) or the simplification of class identity to the more exclusive "White working class" (i.e., denoting racial privilege; Mondon \& Winter, 2019). This would appeal to collective narcissists, for instance, US collective narcissists are likely to agree that historically dominant groups are most ingroup prototypical (and so most deserving; see Golec de Zavala et al., 2019). The sharing of the narcissistic view of the group fosters perceived loss of entitlements at the collective group level-what is deserved (but unmet) as the "true" national group members-construed as lack of proper recognition for the national ingroup, which can then be further mobilized with the populist message of renewed ingroup recognition. This has its real "world-making" consequences through collective action and political support (Elcheroth et al., 2011). 


\section{Limitations and future directions}

Although the present results allow for important insights into the specific ideological predictors of the Capitol attacks and into the role of national collective narcissism in inspiring support for the populist leader to the point of acceptance of undemocratic procedures, the presented results are correlational. As such they do not allow for any firm statements regarding the directionality of the relationship between collective narcissism and support for populist leaders and their undemocratic means.

Study 3 provides an indication of the relative impact of leaders' messaging across variables that have shown to motivate voting preferences, which was central to our hypothesis. However, the design used only allowed us to assess these messages comparatively and allows for relatively uniform preferences across the leadership messages. Furthermore, assessing the differences between predictors was exploratory; comparisons between collective narcissism, right-wing authoritarianism, and social dominance orientation should be replicated and extended by future studies. Future research could also use a categorical outcome measure (i.e., a ballot box) to distinguish the different preferences.

Our data do not allow for any insight into the "chicken-and-egg" problem involved in the identity leadership dynamic (e.g., social identities considered both as cognitive representations as well as social communication and practice; Elcheroth et al., 2011), with leaders both "reading" the motivations involved in different social identities and "shaping" the content of those identities (Mols \& Jetten, 2020). The performative opportunities for social identity enactment have been put forward to resolve this problem, for example, at Trump rallies where the conception of the group is played out and shared (e.g., through violence to protestors, mocking the media), which can then be expressed at the national level (Reicher et al., 2018). With this in mind, collective narcissism research would profit from longitudinal studies conducted during populists' election campaigns (e.g., France's upcoming election). It is expected that as populists foster threat to collective significance, collective narcissism would increase alongside aggression toward minorities and support for the populist party. This follows from research that shows collective narcissism increases following social identity threat to ingroup distinctiveness (Guerra et al., 2020).

Last, further research is needed on the social conditions, which increase collective narcissism. Research into the antecedents of populism indicates that it is more strongly endorsed by higherstatus groups who are threatened by a "fear of falling," that is, by a loss of privilege through status instability, such as increases in economic inequality (Jay et al., 2019; Jetten, 2019). If this is the case, we would expect collective narcissism to increase under these conditions. This effect might be moderated by individual narcissism (a predictor of collective narcissism), with its emphasis on self-enhancement and competitive social comparisons (Campbell et al., 2000).

\section{DATA AVAILABILITY STATEMENT}

Study 3 was conducted as the fulfillment of the master's degree by the first author. The paper includes statements of sample size estimation and data exclusions, all data and materials for the three studies can be found in the Supplemental Material: http://doi.org/10.17605/OSF.IO/4PJCN

The preregistration of hypothesis and material for Study 2: https://aspredicted.org/42665.pdf

\section{OPEN RESEARCH BADGES}

at This article has earned Open Data and Open Materials badges. The research in this paper is not preregistered, but the authors have made available all data, analytic methods (e.g., code), and study materials at the Open Science Framework (https://osf.io/4pjcn/). 


\section{REFERENCES}

Abramowitz, A. \& McCoy, J. (2019) United states: racial resentment, negative partisanship, and polarization in Trump's America. The ANNALS of the American Academy of Political and Social Science, 681(1), 137-156. https: //doi.org/10.1177/0002716218811309

Aggarwal, M. (2021) Trump asks supporters for more money in CPAC speech after raising \$250 million for his Stop the Steal campaign. The Independent, 5 March. https://www.independent.co.uk/news/world/americas/ us-politics/trump-supporters-money-cpac-speech-b1808998.html

Altemeyer, B. (1988) Enemies of freedom: understanding right-wing authoritarianism. London: Jossey-Bass.

Ashmore, R.D., Deaux, K. \& McLaughlin-Volpe, T. (2004) An organizing framework for collective identity: articulation and significance of multidimensionality. Psychological Bulletin, 130(1), 80. https://doi.org/10.1037/ 0033-2909.130.1.80 PMID: 14717651

Bale, T. (2018) Who leads and who follows? The symbiotic relationship between UKIP and the Conservatives-and populism and Euroscepticism. Politics, 38(3), 263-277. https://doi.org/10.1177/0263395718754718

Bartusevičius, H., van Leeuwen, F. \& Petersen, M.B. (2020) Dominance-driven autocratic political orientations predict political violence in Western, Educated, Industrialized, Rich, and Democratic (WEIRD) and non-WEIRD samples. Psychological Science, 31(12), 0956797620922476. https://doi.org/10.1177/0956797620922476

Bocian, K., Cichocka, A. \& Wojciszke, B. (2021) Moral tribalism: moral judgments of actions supporting ingroup interests depend on collective narcissism. Journal of Experimental Social Psychology, 93, 104098. https://doi.org/ 10.1016/j.jesp.2020.104098

Bos, L., Schemer, C., Corbu, N., Hameleers, M., Andreadis, I., Schulz, A., Schmuck, D., Reinemann, C. \& Fawzi, N. (2020) The effects of populism as a social identity frame on persuasion and mobilisation: evidence from a 15country experiment. European Journal of Political Research, 59(1), 3-24. https://doi.org/10.1111/1475-6765.12334

Campbell, W.K., Reeder, G.D., Sedikides, C. \& Elliot, A.J. (2000) Narcissism and comparative self-enhancement strategies. Journal of Research in Personality, 34(3), 329-347. https://doi.org/10.1006/jrpe.2000.2282

Capelos, T. \& Katsanidou, A. (2018) Reactionary politics: explaining the psychological roots of anti preferences in European integration and immigration debates. Political Psychology, 39(6), 1271-1288. https://doi.org/10.1111/ pops. 12540

Citrin, J., Wong, C. \& Shabo, J. (2001) The meaning of american national identity. In: Ashmore, R.D., Jussim, L.J.\& Wilder, D. (Eds.) Social identity, intergroup conflict, and conflict reduction. Oxford: Oxford University Press. pp. 71-100.

Connolly, G. \& Riotta, C. (2021) House impeaches Donald Trump for inciting a bloody insurrection at the US Capitol. The Independent, 15 January. https:/www.independent.co.uk/news/world/americas/us-politics/ trump-impeachment-house-vote-capitol-b1786894.html

Cook, A.C., Hill, N.J., Trichka, M.I., Hwang, G.J. \& Sommers, P.M. (2017) Who voted for Trump in 2016?. Open Journal of Social Sciences, 05(07), 199. https://doi.org/10.4236/jss.2017.57013

Crawford, J., Brady, J., Pilanski, J. \& Erny, H. (2013) Differential effects of right-wing authoritarianism and social dominance orientation on political candidate support: the moderating role of message framing. Journal of Social and Political Psychology, 1(1), 5-28. https://doi.org/10.5964/jspp.vli1.170

Dahl, R.A. (2008) Democracy and its critics. New Haven, CT: Yale University Press.

Donald Trump's address to United Nations. (2020) Donald Trump Speech 2020 UN General Assembly Transcript. Retrieved March 10th, 2021, from https://www.rev.com/blog/transcripts/ donald-trump-speech-2020-un-general-assembly-transcript

Donald Trump's address to United Nations. (2018) Full text: Trump's 2018 UN speech transcript. POLITICO. Retrieved March 10th, 2021, from https://politi.co/2NEe8Rh

Duckitt, J. (2001) A dual-process cognitive-motivational theory of ideology and prejudice. Advances in Experimental Social Psychology, 33, 41-113. https://doi.org/10.1016/S0065-2601(01)80004-6

Duckitt, J., Bizumic, B., Krauss, S.W. \& Heled, E. (2010) A tripartite approach to right-wing authoritarianism: the authoritarianism-conservatism-traditionalism model. Political Psychology, 31(5), 685-715. https://doi.org/10.1111/ j.1467-9221.2010.00781.x

Duckitt, J. \& Sibley, C.G. (2010) Personality, ideology, prejudice, and politics: a dual-process motivational model. Journal of Personality, 78(6), 1861-1894. https://doi.org/10.1111/j.1467-6494.2010.00672.x PMID: 21039534 
Dunwoody, P.T. \& Plane, D.L. (2019) The influence of authoritarianism and outgroup threat on political affiliations and support for antidemocratic policies. Peace and Conflict: Journal of Peace Psychology, 25(3), 198-210. https: //doi.org/10.1037/pac0000397

Elcheroth, G., Doise, W. \& Reicher, S. (2011) On the knowledge of politics and the politics of knowledge: how a social representations approach helps us rethink the subject of political Psychology. Political Psychology, 32(5), 729-758. https://doi.org/10.1111/j.1467-9221.2011.00834.x

Federico, C.M. \& Golec de Zavala, A. (2018) Collective narcissism and the 2016 US presidential vote. Public Opinion Quarterly, 82(1), 110-121. https://doi.org/10.1093/poq/nfx048

Feldman, S. \& Stenner, K. (1997) Perceived threat and authoritarianism. Political Psychology, 18(4), 741-770. https: //doi.org/10.1111/0162-895X.00077

Forgas, J.P. \& Lantos, D. (2020) Understanding populism: collective narcissism and the collapse of democracy in Hungary. In: Forgas, J.P., Crano, W.D. \& Fiedler, K. (Eds.) Applications of social psychology: how social psychology can contribute to the solution of real-world problems (pp. 267-291). New York: Routledge. http://www. sydneysymposium.unsw.edu.au/2019/chapters/ForgasSSSP2019\%20.pdf

Golec de Zavala, A. (2019) Collective narcissism and ingroup satisfaction are associated with different emotional profiles and psychological wellbeing. Frontiers in Psychology, 10, 203. https://doi.org/10.3389/fpsyg.2019.00203

Golec de Zavala, A. \& Bierwiaczonek, K. (2021) Male, national, and religious collective narcissism predict sexism. Sex Roles, 84, 680-700. https://doi.org/10.1007/s11199-020-01193-3

Golec de Zavala, A., Cichocka, A., Eidelson, R. \& Jayawickreme, N. (2009) Collective narcissism and its social consequences. Journal of Personality and Social Psychology, 97(6), 1074-1096. PMID: 19968420

Golec de Zavala, A., Cichocka, A. \& Iskra-Golec, I. (2013) Collective narcissism moderates the effect of in-group image threat on intergroup hostility. Journal of Personality and Social Psychology, 104(6), 1019. https://doi.org/ 10.1037/a0032215 PMID: 23586408

Golec de Zavala, A., Dyduch-Hazar, K. \& Lantos, D. (2019) Collective narcissism: political consequences of investing self-worth in the ingroup's image. Political Psychology, 40(S1), 37-74. https://doi.org/10.1111/pops.12569

Golec de Zavala, A. \& Federico, C.M. (2018) Collective narcissism and the growth of conspiracy thinking over the course of the 2016 United States presidential election: a longitudinal analysis. European Journal of Social Psychology, 48(7), 1011-1018. https://doi.org/10.1002/ejsp.2496

Golec de Zavala, A., Guerra, R. \& Simão, C. (2017) The relationship between the Brexit vote and individual predictors of prejudice: collective narcissism, right wing authoritarianism, social dominance orientation. Frontiers in Psychology, 8. 2023. https://doi.org/10.3389/fpsyg.2017.02023

Golec de Zavala, A. \& Keenan, O. (2021) Collective narcissism as a framework for understanding populism. Journal of Theoretical Social Psychology, 5(2), 54-64. https://doi.org/10.1002/jts5.69

Golec de Zavala, A. \& Lantos, D. (2020) Collective narcissism and its social consequences: the bad and the ugly. Current Directions in Psychological Science, 29(3), 273-278. https://doi.org/10.1177/0963721420917703

Golec de Zavala, A., Lantos, D. \& Keenan, O. (2021) Collective narcissism and the motivational underpinnings of the populist backlash. In: Forgas, J.P., Crano, W.D. \& Fiedler, K. (Eds.) The psychology of populism: the tribal challenge to liberal democracy. New York: Routledge.

Golec de Zavala, A., Peker, M., Guerra, R. \& Baran, T. (2016) Collective narcissism predicts hypersensitivity to in-group insult and direct and indirect retaliatory intergroup hostility. European Journal of Personality, 30(6), 532-551. https://doi.org/10.1002/per.2067

Guerra, R., Bierwiaczonek, K., Ferreira, M., Golec de Zavala, A., Abakoumkin, G., Wildschut, T. \& Sedikides, C. (2020) An intergroup approach to collective narcissism: intergroup threats and hostility in four European Union countries. Group Processes \& Intergroup Relations, 1368430220972178. https://doi.org/10.1177/1368430220972178

Hanson, K. \& O’Dwyer, E. (2019) Patriotism and nationalism, left and right: a Q-methodology study of American national identity. Political Psychology, 40(4), 777-795. https://doi.org/10.1111/pops.12561

Harms, P.D., Wood, D., Landay, K., Lester, P.B. \& Vogelgesang, L.G. (2018) Autocratic leaders and authoritarian followers revisited: a review and agenda for the future. The Leadership Quarterly, 29(1), 105-122. https://doi.org/ 10.1016/j.leaqua.2017.12.007

Hawkins, K.A. \& Kaltwasser, C.R. (2017) The ideational approach to populism. Latin American Research Review, 52(4), 513-528. https://doi.org/10.25222/larr.85

Ho, A.K., Sidanius, J., Kteily, N., Sheehy-Skeffington, J., Pratto, F., Henkel, K.E., Foels, R. \& Stewart, A.L. (2015) The nature of social dominance orientation: theorizing and measuring preferences for intergroup inequality 
using the new $\mathrm{SDO}_{7}$ scale. Journal of Personality and Social Psychology, 109(6), 1003-1028. https://doi.org/10. 1037/pspi0000033

Hogg, M.A. \& Gøtzsche-Astrup, O. (2021) Self-uncertainty and populism: why we endorse populist ideologies, identify with populist groups, and support populist leaders. In: Forgas, J.P., Crano, W.D. \& Fiedler, K. (Eds.) The psychology of populism: the tribal challenge to liberal democracy (pp. 197-218). New York: Routledge.

Jay, S., Batruch, A., Jetten, J., McGarty, C. \& Muldoon, O.T. (2019) Economic inequality and the rise of far-right populism: a social psychological analysis. Journal of Community \& Applied Social Psychology, 29(5), 418-428. https://doi.org/10.1002/casp.2409

Jetten, J. (2019) The wealth paradox: prosperity and opposition to immigration. European Journal of Social Psychology, 49(6), 1097-1113. https://doi.org/10.1002/ejsp.2552

Jetten, J., Mols, F. \& Postmes, T. (2015) Relative deprivation and relative wealth enhances anti-immigrant sentiments: the V-curve re-examined. PLoS ONE, 10(10), e0139156. https://doi.org/10.1371/journal.pone.0139156 PMID: 26461497

Jost, J.T., Federico, C.M. \& Napier, J.L. (2009) Political ideology: its structure, functions, and elective affinities. Annual Review of Psychology, 60, 307-337. https://doi.org/10.1146/annurev.psych.60.110707.163600

Kaltwasser, C.R. (2012) The ambivalence of populism: threat and corrective for democracy. Democratization, 19(2), 184-208. https://doi.org/10.1080/13510347.2011.572619

Kosterman, R. \& Feshbach, S. (1989) Toward a measure of patriotic and nationalistic attitudes. Political Psychology, 10(2), 257-274. https://doi.org/10.2307/3791647

Kruglanski, A.W., Molinario, E. \& Sensales, G. (2021) Why populism attracts: on the allure of certainty and dignity. In: Forgas, J. P., Crano, W.D. \& Fiedler, K. (Eds.) The psychology of populism: the tribal challenge to liberal democracy (pp. 158-173). New York: Routledge.

Kunst, J.R., Dovidio, J.F. \& Thomsen, L. (2019) Fusion with political leaders predicts willingness to persecute immigrants and political opponents. Nature Human Behaviour, 3(11), 1180-1189. https://doi.org/10.1038/ s41562-019-0708-1 PMID: 31477913

Lammers, J. \& Baldwin, M. (2020) Make America gracious again: collective nostalgia can increase and decrease support for right-wing populist rhetoric. European Journal of Social Psychology, 50(5), 943-954. https://doi.org/ 10.1002/ejsp.2673

Leach, C.W., Zebel, S., Vliek, M.L.W., Pennekamp, S.F., Doosje, B., Ouwerkerk, J.W. \& Russell, S. (2008) Group-level self-definition and self-investment: a hierarchical (multicomponent) model of ingroup identification. Journal of Personality and Social Psychology, 95(1), 144-165.

Leeper, T.J. \& Slothuus, R. (2014) Political parties, motivated reasoning, and public opinion formation. Political Psychology, 35(S1), 129-156. https://doi.org/10.1111/pops.12164

Lüdecke, D. (2021)_sjPlot: data visualization for statistics in social science_. R package version 2.8.7. Retrieved July 20th, 2021, from https://CRAN.R-project.org/package=sjPlot

MacKinnon, J.G. \& White, H. (1985) Some heteroskedasticity-consistent covariance matrix estimators with improved finite sample properties. Journal of econometrics, 29(3), 305-325. https://doi.org/10.1016/0304-4076(85) 90158-7

Marchlewska, M., Cichocka, A., Panayiotou, O., Castellanos, K. \& Batayneh, J. (2018) Populism as identity politics: perceived ingroup disadvantage, collective narcissism, and support for populism. Social Psychological and Personality Science, 9(2), 151-162. https://doi.org/10.1177/1948550617732393

Mason, L. \& Wronski, J. (2018) One tribe to bind them all: how our social group attachments strengthen partisanship. Political Psychology, 39, 257-277. https://doi.org/10.1111/pops.12485

McCoy, J., Rahman, T. \& Somer, M. (2018) Polarization and the global crisis of democracy: common patterns, dynamics, and pernicious consequences for democratic polities. American Behavioral Scientist, 62(1), 16-42. https://doi.org/10.1177/0002764218759576

Mole, R.C.M., Golec de Zavala, A. \& Ardag, M.M. (2021) Homophobia and national collective narcissism in populist Poland. European Journal of Sociology. [Preprint]. https://discovery.ucl.ac.uk/id/eprint/10122902/1/ Homophobia\%20and\%20collective\%20narcissism\%20in\%20populist\%20Poland\%20\%28final\%29.pdf

Mols, F. \& Jetten, J. (2014) No guts, no glory: how framing the collective past paves the way for anti-immigrant sentiments. International Journal of Intercultural Relations, 43, 74-86. https://doi.org/10.1016/j.ijintrel.2014.08. 014 
Mols, F. \& Jetten, J. (2020) Understanding support for populist radical right parties: toward a model that captures both demand-and supply-side factors. Frontiers in Communication. 5. 83. https://doi.org/10.3389/fcomm.2020. 557561

Mondon, A. \& Winter, A. (2019) Whiteness, populism and the racialisation of the working class in the United Kingdom and the United States. Identities, 26(5), 510-528. https://doi.org/10.1080/1070289X.2018.1552440

Mondon, A. \& Winter, A. (2020) Reactionary democracy: how racism and the populist far right became mainstream. London: Verso Books.

Mudde, C. \& Kaltwasser, C.R. (2018) Studying populism in comparative perspective: reflections on the contemporary and future research agenda. Comparative Political Studies, 51(13), 1667-1693. https://doi.org/10.1177/ 0010414018789490

Napier, J.L., Bettinsoli, M.L. \& Suppes, A. (2020) The palliative function of system-justifying ideologies. Current Opinion in Behavioral Sciences, 34, 129-134. https://doi.org/10.1016/j.cobeha.2020.03.002

Osborne, D., Milojev, P. \& Sibley, C.G. (2017) Authoritarianism and national identity: examining the longitudinal effects of SDO and RWA on nationalism and patriotism. Personality and Social Psychology Bulletin, 43(8), 10861099. https://doi.org/10.1177/0146167217704196 PMID: 28903711

Pagliaro, S., Ellemers, N. \& Barreto, M. (2011) Sharing moral values: anticipated ingroup respect as a determinant of adherence to morality-based (but not competence-based) group norms. Personality and Social Psychology Bulletin, 37(8), 1117-1129. https://doi.org/10.1177/0146167211406906 PMID: 21540366

Pek, J., Wong, O. \& Wong, A. (2018) How to address non-normality: a taxonomy of approaches, reviewed, and illustrated. Frontiers in Psychology, 9, 2104. https://doi.org/10.3389/fpsyg.2018.02104 PMID: 30459683

Pehrson, S., Vignoles, V.L. \& Brown, R. (2009) National identification and anti-immigrant prejudice: individual and contextual effects of national definitions. Social Psychology Quarterly, 72(1), 24-38. https://doi.org/10.1177/ 019027250907200104

Pinheiro, J., Bates, D., DebRoy, S., Sarkar, D., Heisterkamp, S., Van Willigen, B. \& Ranke, J. (2017) Package 'nlme'. Linear and nonlinear mixed effects models. Retrieved July 20th, 2021, from http://cran.rapporter.net/web/ packages/nlme/nlme.pdf

Pustejovsky, J.E. \& Tipton, E. (2018) Small-sample methods for cluster-robust variance estimation and hypothesis testing in fixed effects models. Journal of Business \& Economic Statistics, 36(4), 672-683. https://doi.org/10.1080/ 07350015.2016.1247004

Pratto, F., Çidam, A., Stewart, A.L., Zeineddine, F.B., Aranda, M., Aiello, A., et al. (2013) Social dominance in context and in individuals: contextual moderation of robust effects of social dominance orientation in 15 languages and 20 countries. Social Psychological and Personality Science, 4(5), 587-599. https://doi.org/10.1177/1948550612473663

Pratto, F., Sidanius, J., Stallworth, L.M. \& Malle, B.F. (1994) Social dominance orientation: a personality variable predicting social and political attitudes. Journal of Personality and Social Psychology, 67(4), 741-763. https://doi. org/10.1037/0022-3514.67.4.741

Core Team R. (2013) R: a language and environment for statistical computing. Vienna: R Foundation for Statistical Computing.

Reicher, S.D. \& Haslam, S.A. (2016) The politics of hope: Donald Trump as an entrepreneur of identity. Scientific American, 19 November. https://www.scientificamerican.com/article/ the-politics-of-hope-donald-trump-as-an-entrepreneur-of-identity/

Reicher, S.D., Haslam, S.A. \& Platow, M.J. (2018) Shared social identity in leadership. Current Opinion in Psychology, 23, 129-133. https://doi.org/10.1016/j.copsyc.2018.08.006 PMID: 30237055

Reicher, S.D., Hopkins, N., Levine, M. \& Rath, R. (2005) Entrepreneurs of hate and entrepreneurs of solidarity: social identity as a basis for mass communication Communication. International Review of the Red Cross, 87(860), 621-638.

Reynolds, K.J., Turner, J.C., Branscombe, N.R., Mavor, K.I., Bizumic, B. \& Subašić, E. (2010) Interactionism in personality and social psychology: an integrated approach to understanding the mind and behaviour. European Journal of Personality, 24(5), 458-482. https://doi.org/10.1002/per.782

Riley-Smith, B. (2020) Donald Trump dubs Joe Biden 'the destroyer of American greatness' in 70minute convention speech. The Telegraph, 28 August. https:/www.telegraph.co.uk/news/2020/08/28/ donald-trump-speech-joe-biden-destroyer-america, n-greatness-says/

Schönbrodt, F.D. \& Perugini, M. (2013) At what sample size do correlations stabilize? Journal of Research in Personality, 47(5), 609-612. https://doi.org/10.1016/j.jrp.2013.05.009 
Selvanathan, H.P., Lickel, B. \& Jetten, J. (2021) Collective psychological ownership and the rise of reactionary counter-movements defending the status quo. British Journal of Social Psychology, 60(2), 587-609. https://doi. $\operatorname{org} / 10.1111 /$ bjso.12418

Sengupta, N.K., Osborne, D. \& Sibley, C.G. (2019) On the psychological function of nationalistic "whitelash". Political Psychology, 40(4), 759-775. https://doi.org/10.1111/pops.12563

Sides, J., Tesler, M. \& Vavreck, L. (2018) Hunting where the ducks are: activating support for Donald Trump in the 2016 Republican primary. Journal of Elections, Public Opinion and Parties, 28(2), 135-156. https://doi.org/10. 1080/17457289.2018.1441849

Smith, E.R. \& Mackie, D.M. (2015) Dynamics of group-based emotions: insights from intergroup emotions theory. Emotion Review, 7(4), 349-354. https://doi.org/10.1177/1754073915590614

Sprong, S., Jetten, J., Wang, Z., Peters, K., Mols, F., Verkuyten, M., Bastian, B., Ariyanto, A., Autin, F., Ayub, N., Badea, C., Besta, T., Butera, F.G., Costa-Lopes, R., Cui, L., Fantini, C., Finchilescu, G., Gaertner, L., Gollwitzer, M., ... \& Wohl, M.J.A. (2019) “Our country needs a strong leader right now”: economic inequality enhances the wish for a strong leader. Psychological Science, 30(11), 1625-1637. https://doi.org/10.1177/0956797619875472 PMID: 31566081

Spruyt, B., Keppens, G. \& Van Droogenbroeck, F. (2016) Who supports populism and what attracts people to it? Political Research Quarterly, 69(2), 335-346. https://doi.org/10.1177/1065912916639138

Tidman, Z. (2021) Far-right Le Pen could win French presidency in 2022, minister warns. The Independent, 14 February. https://www.independent.co.uk/news/world/europe/ marine-le-pen-2020-france-election-bruno-le-maire-b1801918.html

Turner-Zwinkels, F., van Zomeren, M. \& Postmes, T. (2015) Politicization during the 2012 US presidential elections: bridging the personal and the political through an identity content approach. Personality and Social Psychology Bulletin, 41(3), 433-445. https://doi.org/10.1177/0146167215569494 PMID: 25630374

Wickham, H., Averick, M., Bryan, J., Chang, W., McGowan, L.D., François, R., Grolemund, G., Hayes, A., Henry, L., Hester, J., Kuhn, M., Lin, T., Miller, P.E., Bache, S.M., Müller, K., Ooms, J., Robinson, D., Seidel, D.P., Spinu, V., .. \& Yutani, H. (2019) Welcome to the tidyverse. Journal of Open Source Software, 4(43), 1686. https://doi. org/10.21105/joss.01686

Williams, D.K. (2011) The GOP's abortion strategy: why pro-choice republicans became pro-life in the 1970s. Journal of Policy History, 23(4), 513-539. https://doi.org/10.1017/S0898030611000285

Wohl, M.J.A. \& Stefaniak, A. (2020) Collective nostalgia and the desire to make one's group great again. In: Forgas, J.P., Crano, W.D. \& Fiedler, K. (Eds.) Applications of social psychology: how social psychology can contribute to the solution of real-world problems (pp. 292-311). New York: Routledge.

Womick, J., Rothmund, T., Azevedo, F., King, L.A. \& Jost, J.T. (2019) Group-based dominance and authoritarian aggression predict support for Donald Trump in the 2016 U.S. presidential election. Social Psychological and Personality Science, 10(5), 643-652. https://doi.org/10.1177/1948550618778290

Woodward, A. (2021) Capitol police were ordered to hold back against rioters, watchdog report finds. The Independent, 14 April. https://www.independent.co.uk/news/world/americas/us-politics/ congress-itself-is-the-target-b1831406.html

\section{AUTHOR BIOGRAPHIES}

Oliver Keenan is a doctoral student at the Department of Psychology at Goldsmiths, University of London, conducting research at Prejudice Lab.

Agnieszka Golec de Zavala is a senior lecturer at the Department of Psychology at Goldsmiths. She is the lead investigator at Prejudice Lab, http://collectivenarcissism.com/.

How to cite this article: Keenan O. \& de Zavala A.G. Collective narcissism and weakening of American democracy. Anal Soc Issues Public Policy. (2021);21:237-258. https://doi.org/10.1111/asap.12274 